\title{
Physiological Aspects Related to Tolerance of Spring Wheat Cultivars to Septoria tritici Blotch
}

\author{
E. Zuckerman, A. Eshel, and Z. Eyal
}

Department of Plant Sciences, The George S. Wise Faculty of Life Sciences, Tel Aviv University, Tel Aviv 69978, Israel. Accepted for publication 20 September 1996.

\section{ABSTRACT}

Zuckerman, E., Eshel, A., and Eyal, Z. 1997. Physiological aspects related to tolerance of spring wheat cultivars to Septoria tritici blotch. Phytopathology 87:60-65.

The susceptible wheat cultivar Miriam exhibited tolerance under severe infection of Septoria tritici blotch (STB). Nethouse and greenhouse trials confirmed former field results in which losses in grain weight of 'Miriam' wheat due to STB infection were significantly lower than those of the susceptible cultivar Barkai, under equivalent severity and the same disease progress curve. Several physiological mechanisms that may explain this tolerance of 'Miriam' wheat were studied. A comparison between protected and infected plants proved that carbohydrate reserves in the culms and other vegetative plant parts did not account for the lower losses in grain weight of 'Miriam'. Each tiller was shown to be independent in its supply of carbohydrates to its grains, and no import from secondary tillers was observed. Differences in the ratio between grain weight and vegetative biomass could not explain the sustained grain filling of infected plants of 'Miriam'. The daily balance of $\mathrm{CO}_{2}$ exchange of the ears was negative, since carbon fixation by the spike in the light was more than counterbalanced by night time spike respiration. Radioisotope studies revealed that mature, infected 'Miriam' plants maintained as large a percentage of the carbohydrates fixed at the vegetative stage and early grain filling as healthy plants. On the other hand, under the same conditions, infected 'Barkai' plants lost a larger fraction of these carbohydrates. The rate of carbon fixation per unit of chlorophyll and per residual green leaf area of infected 'Miriam' was higher than in healthy plants. It is proposed that this enhancement of photosynthesis in residual green tissue of infected plants of the tolerant cultivar Miriam compensates for the loss of photosynthesizing tissue due to STB.

Additional keywords: Mycosphaerella graminicola, Triticum aestivum.
Severe epidemics of Septoria tritici blotch (STB) of wheat (Triticum aestivum L.), incited by Mycosphaerella graminicola (Fuckel) Schröter ex Cohn (anamorph Septoria tritici Roberge ex Desmaz.), cause considerable losses in wheat yield (15). Under severe epidemics, the pathogen may cause significant reductions in grain weight and also may reduce the number of kernels per spike $(9,32)$. Grain filling may be affected by reduced area of photosynthetically active tissue, enhanced respiration and transpiration, or disturbance in the translocation of assimilates to the spike $(9,33)$. The impact of these stress factors on grain filling is determined by the time-course and the magnitude of the buildup of symptoms on photosynthesizing plant tissues relative to the plant growth (26).

Insignificant reductions in yield under disease stress in susceptible barley, oat, and wheat cultivars were reported for several foliar pathogens $(5,6,12,15,16,18,21,23)$. The susceptible bread wheat cultivar Miriam maintained kernel weight under severe epidemics of STB, mechanical defoliation, and chemical desiccation $(33,34)$. The ability of this cultivar to endure the adverse effect of $S$. tritici on kernel growth was recorded for several years and various trial environments, and was not isolate specific (34).

One possible explanation for tolerance to plant pathogens relates to the storage of carbohydrates in leaves and stems and their translocation to the spike after anthesis $(12,17)$. Gaunt and Wright (17) suggested that the effect of disease on the storage and utilization of stem reserves depends on the time of the epidemic development, its duration, and the potential yield of the crop.

Compensation by carbohydrate supply from unaffected tissues was suggested by Zilberstein et al. (33) as a possible mechanism

Corresponding author: Z. Eyal; E-mail address: zahir@post.tau.ac.il

Publication no. P-1996-1101-01R

(C) 1997 The American Phytopathological Society responsible for grain filling in tolerant cultivars under STB stress. Cornish et al. (9) proposed that translocation of assimilates from stem to the grain and delayed leaf senescence could compensate for the lower rate of assimilation in tolerant, STB-infected plants. However, the mechanisms that cause certain wheat cultivars or specific plant organs to produce, store, translocate, or remobilize assimilates under disease stress are not well understood.

The aim of the present study is to provide quantitative analysis of photosynthetic capacity and the translocation of assimilates to the filling grain in plants of the tolerant cultivar Miriam and the nontolerant cultivar Barkai infected with $S$. tritici, which may explain the tolerance of 'Miriam' to Septoria tritici blotch.

\section{MATERIALS AND METHODS}

Plants. The experiments were conducted with the susceptible, spring bread wheat (Triticum aestivum) cultivars Barkai (YT//NRN/BVR/3/FA/4/CH53//NRN/BVR/3/YQ54/4/2*MERAV, The Volcani Center, Bet Dagan, Israel) and Miriam (CH53//NRN/ BVR/3/YQ54/4/2*MERAV, The Volcani Center).

Nethouse and greenhouse trials were conducted in which infected and protected plants were compared. In the nethouses or in temperature-controlled greenhouses $\left(20 \pm 2^{\circ} \mathrm{C}\right)$, plants were grown in 1-liter pots filled with potting medium (peat moss, volcanic ash, water adsorbents, and slow release fertilizers).

Fungus. Two Israeli isolates of $S$. tritici were used in the trials, ISR398 (ATCC 48507) isolated from cv. Hazera 84 in 1972 at Kibbutz Daliah, and ISR8036 isolated from cv. Shafir in 1980 at Kibbutz Erez. Both isolates are virulent on 'Barkai' and 'Miriam'. Conidial cultures were prepared by inoculating sucrose $(3 \%)$ and yeast extract (1\%) medium ( $75 \mathrm{ml}$ in $250-\mathrm{ml}$ Erlenmeyer flasks). Cultures were maintained on a reciprocal shaker for 4 to 6 days at $18^{\circ} \mathrm{C}$. Inoculation in the nethouse was performed on rainy or dewy 
nights with $1 \times 10^{8}$ conidia $\mathrm{ml}^{-1}$ with the aid of a low volume/low pressure sprayer at weekly intervals, starting at the detection of the third node-growth stage 33 (GS33) (30). Uninoculated, fungicide-protected (three applications of Folicur [terbutrazole 250 emulsified concentrated] at a rate of $500 \mathrm{ml} / \mathrm{ha}$ ) plants were used as a control treatment for assessing losses in yield components in the nethouse trails. Folicur was applied to ensure protection against leaf rust of wheat (Puccinia recondita f. sp. tritici), to which the two cultivars are susceptible. In the greenhouse trials, plants were inoculated with $1 \times 10^{8}$ conidia ml ${ }^{-1}$ at seven weekly intervals with the aid of a low volume/low pressure sprayer starting at the third node (GS33). Inoculated plants were placed in a humidity chamber within a temperature-controlled room $(20 \pm$ $2{ }^{\circ} \mathrm{C}$ ) where mist was supplied by a humidifier for the 48 -h incubation period.

Disease assessment. Average percent pycnidia coverage and necrosis on the three uppermost leaves of 20 plants per treatment was assessed at 10- to 14-day intervals from the onset of visible symptoms in the nethouse and greenhouse trials using the Eyal and Brown (14) standard drawing scale. The area under the disease progress curve (AUDPC) procedure (26) was used to compare the progression of symptoms between the cultivars.

Thousand-kernel weight and harvest index. Thousand-kernel weight (TKW) of grains in central or lateral spikes and harvest index (HI) (the ratio of economic yield to total aboveground biomass) were used as yield measures. The effect of reduction in source size by infection, or by mechanical defoliation, and the effect of reduction in sink size on grain filling of the two cultivars were assessed in STB-infected and Folicur-protected nethousegrown plants of 'Barkai' and 'Miriam'. Ten plants in two replicates were assigned to each treatment. The defoliation treatment included removal of the flag leaf and the flag leaf minus one immediately after anthesis. Sink size was reduced by removal of half the grains along the axis (degrained) of the spike of the central tiller 10 days past anthesis $(2,3,20)$. Either grain removal or defoliation was performed on Folicur-protected and infected plants of each cultivar, and the results were statistically compared by twoway analysis of variance with untreated controls of the four plant groups (two cultivars $\times$ protected/infected).

Fixation and translocation of ${ }^{14} \mathrm{C}$. Fixation, translocation, and storage of carbohydrates in different plant organs in central and lateral tillers were assessed in the nethouse in two separate trials. Radioactively labeled carbon dioxide $\left(7.4 \mathrm{MBq}^{14} \mathrm{CO}_{2}\right.$, released from $\mathrm{NaH}^{14} \mathrm{CO}_{3}$ solution by excess of lactic acid) was applied to groups of 10 plants sealed in transparent polyethylene bags. For every treatment (protected or infected) and every cultivar (Miriam or Barkai), 50 plants were labeled at GS41 and 40 plants at GS71.

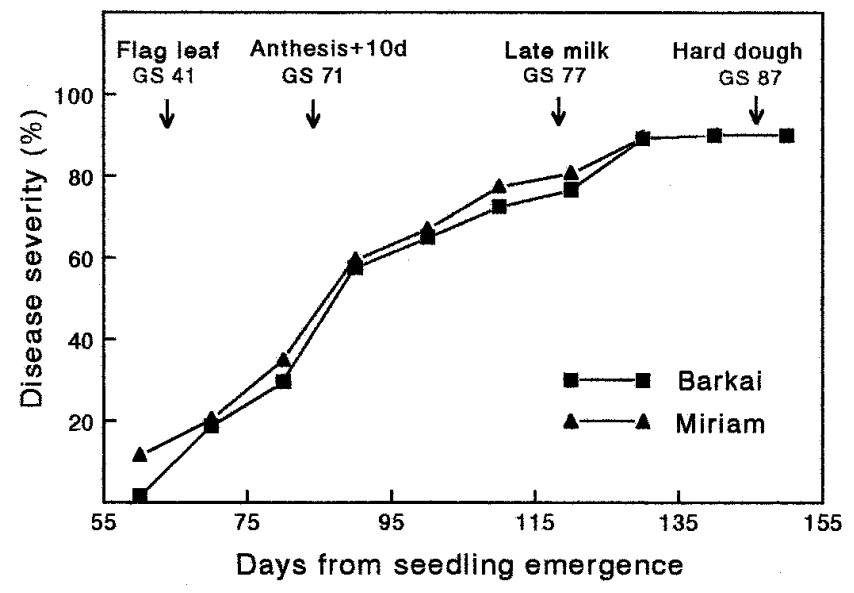

Fig. 1. The progression of Septoria tritici blotch of wheat expressed in percent pycnidia coverage on the three uppermost leaves on nethouse-grown plants of the spring bread wheat cultivars Barkai and Miriam.
The bags remained sealed for 8 h (9 a.m. to 5 p.m.) to allow photosynthetic fixation of the labeled carbon. Plants labeled at GS41 (flag leaf sheath extending) were harvested at four growth stages: $24 \mathrm{~h}$ after $\mathrm{CO}_{2}$ application, 10 days after anthesis, early dough stage (GS77), and maturity (GS87). Plants labeled at GS71 (kernel water ripe) were harvested at three growth stages: $24 \mathrm{~h}$ after $\mathrm{CO}_{2}$ application, early dough stage, and maturity.

Distribution of the radioactive carbohydrates was studied by autoradiography in four randomly selected plants of each cultivar on the seven sampling dates from each of the two treatments (infected or protected). All tillers of each plant were mounted on a flat board, and their silhouette was recorded by a photocopier. An X-ray film (CURIX RP2 100 AFW; Agfa-Gevaert, Mortsel, Belgium) sheet was laid over the plant and pressed to it by another board. The whole mount was covered by a black plastic bag and thick aluminum foil and exposed for 30 days at $-20^{\circ} \mathrm{C}$. The films were developed according to the manufacturer's specifications.

For quantitative analysis of ${ }^{14} \mathrm{C}$ partition, 10 plants of each cultivar were randomly selected on the seven sampling dates from each of the two treatments (infected or protected). The central tillers were divided into parts (leaves, culm, roots, and spike), and the samples were kept frozen at $-20^{\circ} \mathrm{C}$ until extraction. Each plant sample was ground for $1 \mathrm{~min}$ in a blender in $100 \mathrm{ml}$ of $70 \%$ ethanol. Soluble carbohydrates were extracted in ethanol for $1 \mathrm{~h}$ at $70^{\circ} \mathrm{C}$. The extract was separated from the insoluble fraction by vacuum filtration. The dry material was weighed, and samples $(500 \mu \mathrm{l}$ of the liquid fraction or 20 to $60 \mathrm{mg}$ of the solid fraction) were transferred to 3-ml counting vials with 2.5 $\mathrm{ml}$ of scintillation liquid (Safe Fluor; Lumac/3M bv, Schaesberg, the Netherlands). The $14 \mathrm{C}$ content was determined by a liquid scintillation counter (Tri-Carb 1500; Packard Instrument Co., Downers Grove, IL).

Photosynthesis and respiration. Photosynthesis and respiration of the three intact upper leaves or of the intact spikes were determined in two separate experiments in greenhouse-grown plants. Each of the experiments consisted of 10 plants per treatment (infected or protected), replicated twice. An infrared gas analyzer (IRGA, MK-223, Analytical Development Co. Ltd., Haddesdon, Hertfordshire, United Kingdom) with a closed, temperature-controlled, 8-liter chamber (Sirigor; Siemens AG, Erlangen, Germany) at $24^{\circ} \mathrm{C}$ was used for measuring carbon fixation and respiration rates. Measurements of photosynthesis were conducted under light $\left(1,600 \mu \mathrm{E} \mathrm{m}^{-2} \mathrm{~s}^{-1}\right)$ supplied by a halogen lamp, and respiration measurements were done in the dark. The total and green leaf areas of the tested plants were measured, and the chlorophyll content was determined by the method of Moran (22).

Data analysis. A two-way analysis of variance and multiple range tests were performed on the effect of STB on grain weight and the fixation of ${ }^{14} \mathrm{CO}_{2}$ in whole plants and spikes using the 1990 BMDP Statistical Software (11).

TABLE 1. The effect of Septoria tritici blotch and changes in source/sink relationships on kernel weight in nethouse-grown plants of the wheat cultivars Barkai and Miriam

\begin{tabular}{|c|c|c|c|c|c|}
\hline \multirow[b]{2}{*}{ Treatment } & \multirow[b]{2}{*}{ Spike } & \multicolumn{2}{|c|}{$\begin{array}{c}\text { Thousand-kernel } \\
\text { weight } \\
\text { (g) }\end{array}$} & \multicolumn{2}{|c|}{$\begin{array}{l}\% \text { change vs. } \\
\text { protected whole } \\
\text { spike }\end{array}$} \\
\hline & & Barkai & Miriam & Barkai & Miriam \\
\hline Protected & Whole & $35.8 \mathrm{~b}^{\mathrm{y}}$ & $37.3 \mathrm{~b}$ & $\ldots$ & ( \\
\hline Protected & Half & $48.8 \mathrm{a}$ & $45.7 \mathrm{a}$ & +36.3 & +22.3 \\
\hline Protected/defoliated ${ }^{\mathrm{z}}$ & Whole & $29.2 \mathrm{c}$ & $31.3 \mathrm{c}$ & -18.4 & -16.3 \\
\hline Infected & Whole & $29.5 \mathrm{c}$ & $35.5 \mathrm{~b}$ & -17.6 & -4.8 \\
\hline Infected & Half & $43.9 \mathrm{a}$ & $46.0 \mathrm{a}$ & +22.4 & +23.2 \\
\hline
\end{tabular}

y Treatment means within columns followed by the same letter do not differ significantly $(P<0.05)$ as determined by Duncan's Multiple Range Test.

${ }^{\mathrm{z}}$ Flag + flag leaf minus 1 were removed immediately after anthesis. 


\section{RESULTS}

The effect of disease on TKW. The progression of Septoria tritici blotch on the uppermost three leaves of 'Barkai' and 'Miriam' for the same physiological growth stages in the nethouse trial is presented in Figure 1. The disease progress profiles of the two cultivars do not differ statistically at any of the recorded intervals, yet, the loss of TKW in 'Barkai' was three times larger than in 'Miriam' (Table 1). Reducing source size by defoliation of the two upper leaves at the onset of grain filling resulted in similar losses in TKW in the two cultivars. Reducing sink size by removing half the grains of the spike of protected plants resulted in increased kernel weight both in 'Barkai' and 'Miriam'. Degraining of spikes in infected 'Barkai' resulted in a loss of $10.0 \%$ in TKW as compared with a gain of $0.6 \%$ in 'Miriam'.

Harvest index. There were no significant differences between straw dry weight of protected and infected central (1.0 to $1.3 \mathrm{~g}$ ) and lateral $(0.7$ to $1.0 \mathrm{~g})$ tillers of each cultivar in the nethouse trial. The largest effect of STB was on grain weight of central $(44.4 \%)$ and lateral $(43.1 \%)$ tillers of plants of 'Barkai', whereas no reductions were recorded in 'Miriam'. As a result, significant losses in $\mathrm{HI}(>40.0 \%)$ were recorded in both central and lateral tillers of 'Barkai', but not in 'Miriam'.

Translocation of ${ }^{14} \mathrm{C}$. Transport of assimilates from lateral to central tillers was assessed by autoradiography for nethousegrown plants. There was no indication for any transport of labeled assimilates from lateral to central tillers during grain filling. This

TABLE 2. The amount of ${ }^{14} \mathrm{CO}_{2}$ in Folicur-protected and Septoria tritici blotchinfected nethouse-grown plants of Barkai and Miriam wheat cultivars measured after application of the radioisotope (GS41 and GS71) and at the end of grain filling (GS87)

\begin{tabular}{|c|c|c|c|c|c|c|c|}
\hline \multirow[b]{3}{*}{$\begin{array}{l}\text { Wheat } \\
\text { cultivar }\end{array}$} & \multirow[b]{3}{*}{ Treatment } & \multicolumn{6}{|c|}{ Application and sampling of radioisotope } \\
\hline & & \multicolumn{3}{|c|}{ Application GS41 ${ }^{\mathrm{w}}$} & \multicolumn{3}{|c|}{ Application GS71 w } \\
\hline & & $\begin{array}{l}\text { Sample } \\
\text { GS41 }\end{array}$ & $\begin{array}{c}\text { SampleG } \\
\text { S87 }\end{array}$ & $\begin{array}{c}\text { Residual } \\
\%\end{array}$ & $\begin{array}{c}\text { Sample } \\
\text { GS71 }\end{array}$ & $\begin{array}{c}\text { Sample } \\
\text { GS87 }\end{array}$ & $\begin{array}{c}\text { Residual } \\
\%\end{array}$ \\
\hline \multirow[t]{2}{*}{ Barkai } & Prot & $23.6 \mathrm{a}^{\mathrm{y}}$ & $15.4 \mathrm{a}^{\mathrm{z}}$ & 65 & $3.6 \mathrm{a}$ & $2.5 \mathrm{a}$ & 70 \\
\hline & Infected & $30.7 \mathrm{a}$ & $7.8 \mathrm{~b}$ & 25 & $4.5 \mathrm{a}$ & $1.2 \mathrm{~b}$ & 26 \\
\hline \multirow[t]{2}{*}{ Miriam } & $\mathrm{Pr}_{1}$ & $17.7 \mathrm{a}$ & 12. & 70 & 4.0 & 2.8 & 70 \\
\hline & Infected & $23.1 \mathrm{a}$ & $16.1 \mathrm{a}$ & 72 & $4.2 \mathrm{a}$ & $2.8 \mathrm{a}$ & 67 \\
\hline
\end{tabular}

${ }^{\mathrm{w}}$ Application of ${ }^{14} \mathrm{CO}_{2}$ at flag-leaf sheath extending (growth stage 41 ) and at kernel water ripe (growth stage 71) according to Zadoks et al. (31).

x Sampling at GS41 and at hard dough stage (growth stage 87) of plants labeled at GS41, and at GS71 and GS87 of plants labeled at GS71.

${ }^{y} \mathrm{kBq}$ per tiller.

${ }^{\mathrm{z}}$ Means within columns followed by the same letter do not differ significantly $(P$ $<0.05)$ as determined by Duncan's Multiple Range Test.

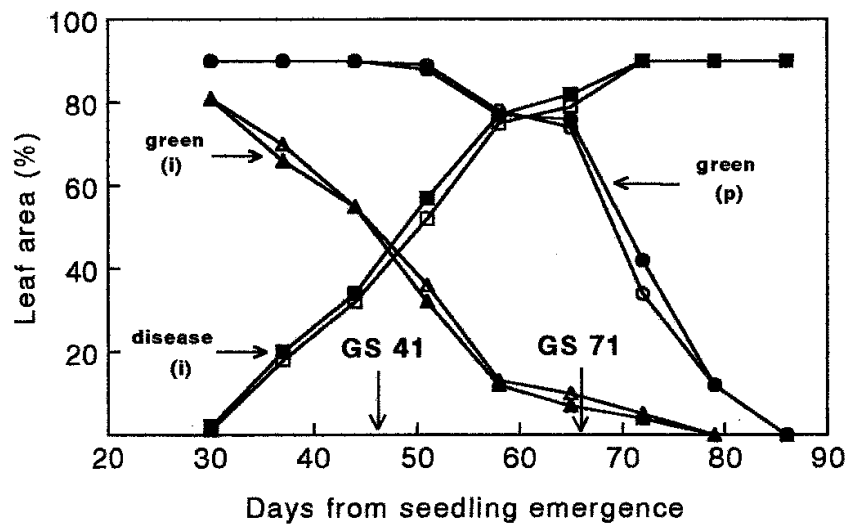

Fig. 2. The progression of disease-affected leaf area (percent pycnidia coverage and necrosis, squares), of percent green leaf area in protected plants (circles), and of residual green leaf area in Septoria tritici blotch-infected plants (triangles) in greenhouse-grown plants of 'Barkai' (closed symbols) and 'Miriam' wheat (open symbols). indicates that each tiller is autonomous in translocating nonstructural carbohydrates (NSC) to its own spike and grains. Autoradiography revealed storage of labeled carbohydrates in the spikes, but not in the culm nodes, of either cultivar.

Carbon fixation at pre- and postanthesis. The contribution of photosynthate from pre- and postanthesis fixation to grain filling was determined in nethouse-grown plants. The fraction of radiolabeled assimilates, fixed at flag leaf sheath extending (GS41) and at kernel water ripe stage (GS71), that remained in the plants until kernel was at the hard dough stage (GS87) was assessed (Table 2). Infected 'Barkai' plants retained a smaller fraction of assimilates from either the pre- or postanthesis application of ${ }^{14} \mathrm{CO}_{2}$ than protected ones. The fraction of label retained in 'Miriam' was the same for infected and protected plants at all ${ }^{14} \mathrm{CO}_{2}$ application times and sampling stages.

Photosynthesis and respiration. The relationships between photosynthesis, respiration, and Septoria tritici blotch were investigated in greenhouse trials. The level of symptoms established on the three uppermost leaves and the loss in green leaf area were similar for the two cultivars (Fig. 2). The amount of green leaf area in infected plants decreased markedly at GS41, whereas, in protected plants, loss in green leaf area was associated with normal senescence that began only at GS71. The AUDPC was larger than the area under the residual green leaf curve in the infected wheat plants. However, necrotic regions bearing pycnidia did not fully coalesce, leaving islands of green leaf tissue.

The content of chlorophyll $\left(\mu \mathrm{g} \mathrm{cm}^{-2}\right)$, the net rate of fixation of $\mathrm{CO}_{2}$ per milligram of chlorophyll, and per square centimeter of total and of residual green leaf area were determined at GS41 and GS71 in two greenhouse experiments. At GS41, a reduction in the chlorophyll content was recorded in infected 'Miriam', but not in 'Barkai', whereas, at GS71, chlorophyll content in the flag leaf was markedly reduced by the pathogen in both cultivars in the two experiments (Table 3). The decrease in the amount of chlorophyll was not accompanied by a corresponding decrease in the fixation rate. The fixation of $\mathrm{CO}_{2}$ per milligram of chlorophyll at GS71 increased markedly in infected leaves of 'Barkai', and to a lesser extent in 'Miriam'.

Two other measures of carbon fixation rate, per tiller and per residual green leaf area, were compared in Figure 3. At GS41, the rates of $\mathrm{CO}_{2}$ fixation per tiller and per unit of residual green leaf area were the same in all four plant groups tested (two cultivars, infected or protected). At GS71, however, they differed markedly between the two cultivars. $\mathrm{CO}_{2}$ fixation per tiller of STB-infected plants was lower by more than sixfold in 'Barkai', as compared with a twofold decrease in 'Miriam'. Moreover, at that growth

TABLE 3. The amount of chlorophyll per square centimeter of flag leaf area, the rate of $\mathrm{CO}_{2}$ fixation per milligram of chlorophyll (chl) and per square centimeter of total leaf area in Folicur-protected and Septoria tritici blotchinfected greenhouse-grown plants of Barkai and Miriam wheat cultivars

\begin{tabular}{|c|c|c|c|c|c|c|c|}
\hline \multirow{3}{*}{$\begin{array}{l}\text { Growth } \\
\text { stage }\end{array}$} & \multirow[b]{3}{*}{ Treatment } & \multirow{2}{*}{\multicolumn{2}{|c|}{$\begin{array}{l}\text { Chlorophyll } \\
\left(\mu \mathrm{g} \mathrm{cm}^{-2}\right)\end{array}$}} & \multicolumn{4}{|c|}{$\mathrm{CO}_{2}$ fixation rates } \\
\hline & & & & \multicolumn{2}{|c|}{$\left(\mu \mathrm{mol} \mathrm{h}^{-1}[\mathrm{mg} \mathrm{chl}]^{-1}\right)$} & \multicolumn{2}{|c|}{$\left(\mu \mathrm{mol} \mathrm{h}^{-1} \mathrm{~cm}^{-2}\right)$} \\
\hline & & Trial I & Trial II & Trial I & Trial II & Trial I & Trial II \\
\hline \multicolumn{8}{|c|}{ Flag leaf extending (GS41) } \\
\hline Barl & Prote & $78.2 \mathrm{a}^{\mathrm{z}}$ & & $12.6 \mathrm{a}$ & & $0.99 \mathrm{a}$ & \\
\hline Barkai & Infec & 75.1 & & 14.1 & & $1.06 \mathrm{a}$ & \\
\hline Miriam & Prote & 75.6 & & 11.4 & & $0.86 \mathrm{a}$ & \\
\hline Miria & Infe & $56.5 \mathrm{~b}$ & & $16.4 \mathrm{a}$ & & $0.93 \mathrm{a}$ & \\
\hline \multicolumn{8}{|c|}{10 days postanth } \\
\hline Barkai & Protected & $60.8 \mathrm{~b}$ & 48 & $33.4 \mathrm{~b}$ & $46.3 \mathrm{ab}$ & $2.03 \mathrm{a}$ & $2.25 \mathrm{a}$ \\
\hline Barkai & Infect & & & $120.7 \mathrm{a}$ & & $0.95 \mathrm{~d}$ & $1.14 \mathrm{~b}$ \\
\hline & & 91. & & $17.3 \mathrm{c}$ & & $1.58 \mathrm{~b}$ & $2.14 \mathrm{a}$ \\
\hline Miriam & Infected & $36.6 \mathrm{c}$ & $34.3 \mathrm{~b}$ & $29.0 \mathrm{~b}$ & $58.3 \mathrm{ab}$ & $1.06 \mathrm{c}$ & $2.00 \mathrm{a}$ \\
\hline
\end{tabular}

${ }^{z}$ Treatment means within columns in each trial at each sampling date followed by the same letter do not differ significantly $(P<0.05)$ as determined by Duncan's Multiple Range Test. 
stage, the fixation of $\mathrm{CO}_{2}$ per square centimeter of residual green leaf area increased threefold in 'Miriam', while a slight decrease was found for 'Barkai'.

A linear relationship $\left(r^{2}=0.792, P<0.05\right)$ existed between TKW and the rate of $\mathrm{CO}_{2}$ fixation per unit of leaf area in two greenhouse trials (Fig. 4). The highest kernel weight was recorded in protected plants of the two cultivars and the lowest in infected 'Barkai'. High kernel weight was recorded in infected 'Miriam' in one trial and low weight in the second trial. The low kernel weight in infected 'Barkai' was strongly associated with the low fixation rate of infected leaves at GS71.

The contribution of $\mathrm{CO}_{2}$ fixed by awns and glumes to the carbohydrate balance of the plant was estimated by measuring lightand dark- $\mathrm{CO}_{2}$ fluxes of intact spikes in the greenhouse-grown plants. The grain filling of these wheat cultivars, under normal agricultural practices in Israel, takes place in March to May when day length is close to $12 \mathrm{~h}$. Therefore, net daily $\mathrm{CO}_{2}$ fluxes by the spikes were estimated by multiplying hourly rates by 12 . Fixation and respiration was significantly lower in spikes of infected 'Barkai' compared with those of protected plants in the two experiments. Somewhat lower fixation and respiration rates were recorded in spikes of infected Miriam plants, yet significant differences with respect to the spikes of protected plants were recorded in the second trial only. In all cases, the net fluxes were negative (Table 4). In spite of the fact that there was no infection by $S$. tritici of glumes and awns in the two cultivars, $\mathrm{CO}_{2}$ fixation by these organs cannot explain the smaller loss in TKW of 'Miriam' under disease conditions.

\section{DISCUSSION}

Plants employ a variety of genetically heritable mechanisms that protect their tissue and their reproductive products from plant pathogens. The different forms of host resistance share mechanisms that retard the growth and the development rate of the pathogens within host tissue. Protection of yield (tolerance) in infected plants was defined by Caldwell and Schafer (6) as the ability of a crop to endure severe epidemics by the pathogen while sustaining only insignificant yield losses, as compared with an infected nontolerant cultivar. This definition of tolerance provides practical outlines for comparing cultivar performance during disease epidemics. Zadoks and Schein (31) added to this definition a parameter that requires comparisons to be made under the same level of injury (symptom expression). All definitions imply that tolerance is a relative phenomenon, since the magnitude and severity of disease and timing of the epidemics with respect to plant

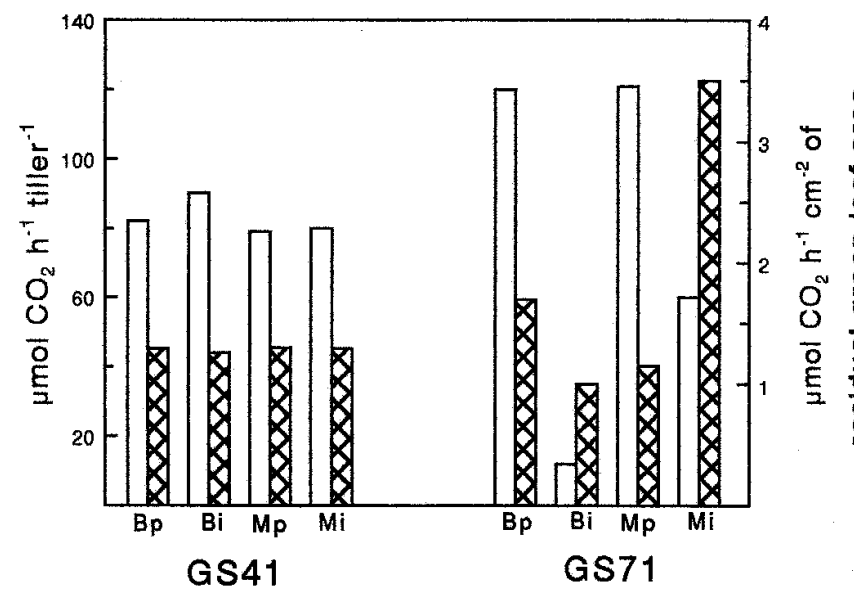

Fig. 3. The fixation of $\mathrm{CO}_{2}$ per tiller (open columns) and per residual green leaf area (hatched columns) in protected (p) and Septoria tritici blotchinfected (i) greenhouse-grown plants of 'Barkai' (B) and 'Miriam' (M) wheat assessed at growth stages GS41 and GS71. development in any given environment may vary from one case to the other.

Storage of carbohydrates and their mobilization to the sink under stress conditions, or compensation in photosynthetic capacity, relative to nondiseased tissue were suggested as possible mechanisms associated with tolerance $(12,18)$. Yet, quantitative data for such, or any other, tolerance mechanism have not been reported.

We have shown here that under equivalent disease progress curves and severity 'Miriam' exhibits significantly smaller losses in TKW than the nontolerant cultivar Barkai. This is in agreement with previous reports $(15,32,33)$ in which limitation in green leaf area by disease, mechanical defoliation, or chemical desiccation (13) all resulted in reduced grain weight. Still, losses in 'Miriam' were significantly lower than in 'Barkai'.

Degraining of half spike at 10 days postanthesis caused an increase in grain weight of protected plants of the two cultivars, indicating that grain size of uninfected plants of these cultivars is determined by sink demands rather than by source size. Such ability to compensate for degraining by increased per grain weight is apparently genotype specific $(4,15,18,33)$. It should be noted that both 'Barkai' and 'Miriam' have a relatively large sink size. It is, therefore, concluded that the tolerance of 'Miriam' to Septoria tritici blotch is not associated with an initially small sink size, as found by Kramer et al. (18) for barley infected with leaf rust. Their conclusion that cultivars that develop a relatively small sink in relation to the source, because of poor adaptation to the test environment, may endure the effect of disease, whereas a high sink/source ratio will characterize nontolerant cultivars, is not applicable to the findings of the current study.

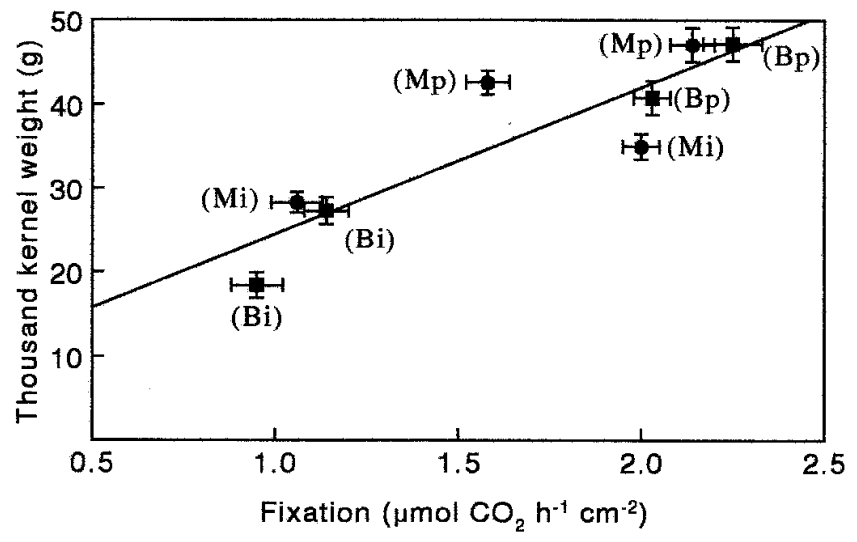

Fig. 4. The linear relationship $\left(r^{2}=0.792, P<0.05\right)$ between the fixation of $\mathrm{CO}_{2}\left(\mu \mathrm{mol} \mathrm{h} \mathrm{h}^{-1} \mathrm{~cm}^{-2}\right)$ and thousand-kernel weight in protected $(\mathrm{p})$ and Septoria tritici blotch-infected (i) plants of 'Barkai' (B) and 'Miriam' (M) wheat, conducted in two greenhouse trials (I - circles, II - squares). The standard error (SE) is given for each mean.

TABLE 4. The contribution of the spike to the daily $\mathrm{CO}_{2}$ flux in Folicurprotected and Septoria tritici blotch-infected plants of Barkai and Miriam wheat cultivars, at GS71 (10 days postanthesis) in two greenhouse experiments

\begin{tabular}{llccc}
\hline Experiment & Treatment & Fixation $^{\mathrm{y}}$ & Respiration $^{\mathrm{y}}$ & Net flux $^{\mathrm{y}}$ \\
\hline I & & & & \\
Barkai & Protected & $272.4 \mathrm{a}^{\mathrm{z}}$ & $307.2 \mathrm{~b}$ & -34.8 \\
Barkai & Infected & $69.6 \mathrm{~b}$ & $172.8 \mathrm{c}$ & -103.2 \\
Miriam & Protected & $267.6 \mathrm{a}$ & $464.4 \mathrm{a}$ & -196.8 \\
Miriam & Infected & $214.8 \mathrm{a}$ & $424.8 \mathrm{a}$ & -210.0 \\
II & & & & \\
Barkai & Protected & $244.8 \mathrm{ab}$ & $314.4 \mathrm{a}$ & -69.6 \\
Barkai & Infected & $46.8 \mathrm{c}$ & $210.0 \mathrm{~b}$ & -163.2 \\
Miriam & Protected & $279.6 \mathrm{a}$ & $291.6 \mathrm{a}$ & -12.0 \\
Miriam & Infected & $187.2 \mathrm{~b}$ & $199.2 \mathrm{~b}$ & -12.0 \\
\hline
\end{tabular}

${ }^{y} \mathrm{mmol} \mathrm{CO}_{2}$ spike $^{-1}$ day $^{-1}$.

${ }^{z}$ Treatment means within columns followed by the same letter do not differ significantly $(P<0.05)$ as determined by Duncan's Multiple Range Test. 
The possibility that the observed tolerance can be explained by remobilization of carbohydrates stored during the vegetative stages (12) was not supported by the results of the tracer experiments. The two cultivars did not differ in the amounts of assimilates fixed at the vegetative stage. However, plants of 'Miriam' retained a larger fraction of these assimilates associated with grain filling than those of 'Barkai'. Assimilates are lost at that period by maintenance respiration. Apparently, in infected 'Miriam' plants, the carbon fixed during grain filling was utilized by respiration less than in protected plants of the two cultivars. Infected plants of 'Barkai' were inferior in that respect and utilized a larger fraction of their NSC for respiration. The tracer experiments gave no indication for transport of radioactive carbon from lateral tillers to the central tiller or vice versa. This indicates that lateral tillers under the Israeli environment (high temperatures and water deficiency towards the end of the growing season) and the trial conditions do not provide a compensatory source of assimilates to the central tiller and, therefore, cannot explain tolerance, as was suggested in other cases $(1,10)$.

Leaves were the major contributors of carbohydrates to grain filling, whereas the net contribution of the spikes was negative. It was suggested (19) that under certain conditions the photosynthesis of spike organs can compensate for loss of photosynthesizing leaf tissue. However, this cannot explain these results. Weyhrich et al. (29) also showed that awn photosynthesis did not contribute significantly to kernel weight. In the current study, kernel weight was found to be highly correlated with the net $\mathrm{CO}_{2}$ fixation rate per square centimeter of leaf area. It is, therefore, concluded that the tolerance of 'Miriam' to Septoria tritici blotch results from the relatively high fixation rate per unit of infected leaves rather than from storage and remobilization of carbohydrates.

These findings are in agreement with the report by Shtienberg (27) on the relationships between fixation rate and losses in yield. It suggests that tolerance reflects the differences in fixation rates during grain filling among infected wheat genotypes. A fivefold reduction in the rate of $\mathrm{CO}_{2}$ fixation per unit of leaf area was recorded in infected 'Barkai' as compared with that of 'Miriam', whereas the rate of fixation per unit tiller of 'Miriam' was three times that of 'Barkai'. The increase in the fixation rate per unit of chlorophyll of 'Miriam' compensated for the loss in chlorophyll in infected plants, while the fixation efficiency of 'Barkai' could compensate for the loss of photosynthesizing leaf area. These findings can explain the differences in the retention of assimilates and in grain weight of infected plants of the two cultivars. The higher rate of $\mathrm{CO}_{2}$ fixation of residual photosynthetic tissue of 'Miriam' under disease stress may explain the tolerance of this cultivar to Septoria tritici blotch.

Several physiological processes determine the relationship between photosynthetic activity and grain filling $(28,32)$. We suggest that the limitation of grain filling by the sink size, which was found in these genotypes, may result from a feedback inhibition of leaf photosynthesis by the developing grains. As the source/sink ratio is reduced under disease conditions, this inhibition may be relieved and higher rates of $\mathrm{CO}_{2}$ fixation per unit of green leaf area are realized.

It is possible that this increased fixation per unit of residual green area can also explain the tolerance of 'Miriam' to chemical desiccation in which leaves were affected, but grain filling was carried on by the less-affected sheath and stems $(9,21,24,25,33)$. Septoria tritici blotch infection and chemical desiccation both leave residual green tissue, but the increased photosynthetic efficiency in the tolerant cultivar can compensate for the loss in the photosynthesizing leaf area. It is, thus, possible that tolerance to Septoria tritici blotch in susceptible wheat cultivars can be recognized in genotypes with an efficient photosynthesizing apparatus of infected tissue together with shorter grain filling duration. Structural and enzymatic parameters associated with photosynthesis may provide further physiological information explaining the differences in STB stress endurance of Miriam-like cultivars (7, $8,16)$.

\section{LITERATURE CITED}

1. Bell, C. J., and Incoll, L. D. 1990. The redistribution of assimilate in field-grown winter wheat. J. Exp. Bot. 41:949-960.

2. Blum, A. 1985. Photosynthesis and transpiration in leaves and ears of wheat and barley varieties. J. Exp. Bot. 36:432-440.

3. Blum, A., Mayer, J., and Golan, G. 1988. The effect of grain number per spike (sink size) on source activity and its water-relations in wheat. J. Exp. Bot. 39:106-114.

4. Buddenhagen, I. W. 1981. Conceptual and practical considerations when breeding for tolerance or resistance. Pages 221-234 in: Plant Disease Control. R. C. Staples and G. H. Toenniessen, eds. John Wiley \& Sons, New York.

5. Caldwell, R. M. 1968. Breeding for general and/or specific plant disease resistance. Pages 263-272 in: Wheat Genetics. K. W. Finlay and K. W. Shepherd, eds. Proc. Intern. Wheat Genet. Symp., 3rd. Australian Academy of Sciences, Canberra, Australia.

6. Caldwell, R. M., and Schafer, J. E. 1958. Tolerance to cereal leaf rust. Science 128:714-715.

7. Carver, B. F., Johnson, R. C., and Rayburn, A. L. 1989. Genetic analysis of photosynthetic variation in hexaploid and tetraploid wheat and their inter-specific hybrids. Photosynth. Res. 20:105-118.

8. Clarke, D. D. 1984. Tolerance of parasitic infection in plants. Pages 119127 in: Plant Diseases: Infection, Damage and Loss. R. K. S. Wood and G. J. Jellis, eds. Blackwell Scientific Publications, Oxford.

9. Cornish, P. S., Baker, G. R., and Murray, G. M. 1990. Physiological responses of wheat (Triticum aestivum) to infection with Mycosphaerella graminicola. Aust. J. Agric. Res. 41:317-327.

10. Davidson, D. J., and Chevalie, P. M. 1992. Storage and remobilization of water-soluble carbohydrates in stems of spring wheat. Crop Sci. 32:186190.

11. Dixon, W. J., Sampson, P., and Mundle, P. 1990. One- and two-way analysis of variance and data screening. Pages 189-212 in: BMDP Statistical Software Manual, Vol. 1. W. J. Dixon, M. B. Brown, L. Engelman, and R. I. Jennrich, eds. University of California Press, Berkeley, CA.

12. Ellis, R. T. 1954. Tolerance to the maize rust Puccinia polysora Underw. Nature 27:1021.

13. Eyal, Z. 1992. The response of field-inoculated wheat cultivars to mixtures of Septoria tritici isolates. Euphytica 61:25-35.

14. Eyal, Z., and Brown, M. B. 1976. A quantitative method for estimating density of Septoria tritici pycnidia on wheat leaves. Phytopathology 66:11-14.

15. Eyal, Z., Scharen, A. L., Prescott, J. M., and van Ginkel, M. 1987. The Septoria diseases of wheat: Concepts and methods of disease management. CIMMYT, Mexico D.F., Mexico.

16. Gaunt, R. E. 1981. Disease tolerance-An indicator of thresholds? Phytopathology 71:915-916.

17. Gaunt, R. E., and Wright, A. C. 1992. Disease-yield relationship in barley. II. Contribution of stored stem reserves to grain filling. Plant Pathol. 41:668-701.

18. Kramer, T., Gildemacher, B. H., van der Ster, M., and Parlevliet, J. E. 1980. Tolerance of spring barley cultivars to leaf rust, Puccinia hordei. Euphytica 29:209-216.

19. Le Cain, D. R., Morgan, J. A., and Zerbi, G. 1989. Leaf anatomy and gas exchange in nearly isogenic semidwarf and tall winter wheat. Crop Sci. 29:1246-1250.

20. Ma, Y. Z., MacKown, C. T., and van Sanford, D. A. 1990. Sink manipulation in wheat: Compensatory changes in kernel size. Crop Sci. 30:1099-1105.

21. Mesterhazy, A., Csosz, M., Manninger, K., and Barabas, Z. 1991. Vertical resistance or tolerance, a methodical challenge? Acta Phytopathol. Entomol. Hung. 26:271-279.

22. Moran, R. 1982. Formulae for determination of chlorophyllous pigments extracted with N,N-dimethylformamide. Plant Physiol. 69:1376-1381.

23. Newton, A. C., and Thomas, W. T. B. 1994. Detection of tolerance of barley cultivars to infection by powdery mildew (Erysiphe graminis f.sp. hordei). Euphytica 75:179-187.

24. Scharen, A. L., and Krupinsky, J. M. 1969. Effect of Septoria nodorum infection on $\mathrm{CO}_{2}$ absorption and yield of wheat. Phytopathology 59:1298-1301.

25. Scharen, A. L., and Taylor, J. M. 1968. $\mathrm{CO}_{2}$ assimilation and yield of Little Club wheat infected by Septoria nodorum. Phytopathology $58: 447-451$

26. Shaner, G., and Finney, R. E. 1977. The effect of nitrogen fertilization on the expression of slow-mildewing resistance in Knox wheat. Phyto- 
pathology 67:1051-1056.

27. Shtienberg, D. 1992. Effects of foliar diseases on gas exchange processes: A comparative study. Phytopathology 82:760-765.

28. Wafford, J. D., and Whitbread, R. 1976. Effects of leaf infections by Septoria nodorum Berk. on the translocation of ${ }^{14} \mathrm{C}$-labelled assimilates in spring wheat. Ann. Bot. 40:83-90.

29. Weyhrich, R. A., Carver, B. F., and Martin, B. C. 1995. Photosynthesis and water-use efficiency of awned and awnletted near-isogenic lines of hard red winter wheat. Crop Sci. 35:172-176.

30. Zadoks, J. C., Chang, T. T., and Konzak, C. F. 1974. A decimal code for the growth stages of cereals. Weed Res. 14:415-421.
31. Zadoks, J. C., and Schein, R. D. 1979. Epidemiology and plant disease management. Oxford University Press, New York.

32. Zamski, E. 1994. Transport and accumulation of carbohydrates in developing seeds: The seed sink. Pages 25-44 in: Seed Development and Germination. J. Kigel and G. Galili, eds. Marcel Dekker, New York.

33. Zilberstein, M., Blum, A., and Eyal, Z. 1985. Chemical desiccation of wheat plants as a simulator of postanthesis speckled leaf blotch stress. Phytopathology 75:226-230.

34. Ziv, O., and Eyal, Z. 1978. Assessment of yield component losses caused in plants of spring wheat cultivars by selected isolates of Septoria tritici. Phytopathology 68:791-796. 